\title{
Two new species of serpulid polychaetes (Annelida) from the Barents Sea
}

\author{
Alexander V. Rzharsky', Elena K. Kupriyanova ${ }^{2}$ and Andrej V. Sikorski ${ }^{3}$
}

\author{
Rzhavsky AV, Kupriyanova EK and Sikorski AV. 2013. Two new species of serpulid polychaetes \\ (Annelida) from the Barents Sea. Fauna norvegica 32: 27-38.
}

\begin{abstract}
Although Scandinavian Arctic polychaete fauna has been extensively investigated, new species are still being found in the Barents Sea. Polychaetes of the family Serpulidae are calcareous tubeworms that are most abundant at low latitudes and less common in Arctic and Antarctic waters. Because recent phylogenetic data indicate that the family Spirorbidae is a clade nested inside Serpulidae, spirorbins are treated here as subfamily Spirorbinae and their traditionally recognized subfamilies are thus lowered to the tribes Paralaeospirini, Spirorbini, Circeini, Romanchellini, Pileolariini and Januini. Here we report two new serpulid species, a filogranin Protis akvaplani sp. n. and a spirorbin Bushiella (Bushiella) barentsii sp. n. collected from off the northern Norwegian coast. Protis akvaplani differs from other species of within the genus by its tube with a high longitudinal keel, six thoracic chaetigerous segments, and short thoracic membranes ending after the 3rd segment. Generic diagnosis of the genus Protis has been emended. Bushiella (B.) barentsii differs from other species of the subgenus Bushiella by morphology of the opercular talon of operculum, incomplete fusing of primary operculum with brood chamber, and large tubes (up to $5 \mathrm{~mm}$ in coil diameter) with 1-2 distinct longitudinal ridges.
\end{abstract}

doi: 10.5324/fn.v31i0.1506. Recieved: 2012-04-26. Accepted: 2012-09-14.

Published on paper and online: 2013-02-13.

Keywords: Polychaeta, Serpulidae, Protis akvaplani sp.n., Bushiella (Bushiella) barentsii sp.n., Barents Sea, Norway

1. A.N. Severtsov Institute of Ecology and Evolution of the Russian Academy of Sciences, Leninskij Prospekt 33,Moscow, 119071, Russiarzhavskij@mail.ru

2. The Australian Museum, 6 College Street, Sydney, NSW 2010, Australia

Elena.kupriyanova@austmus.gov.au

3. Akvaplan-Niva, Fram Centre, 9296 Tromsø, Norway

andrej.sikorski@akvaplan.niva.no

Corresponding author: Alexander V. Rzhavsky

E-mail: rzhavskij@mail.ru

\section{INTRODUCTION}

The European Arctic and especially Scandinavian polychaete fauna has been extensively investigated, although less is known about the fauna of the Western and Central Arctic. Even in the Barents Sea, the most thoroughly studied area, new species are still being found (e.g., Chambers \& Woodham 2003, Koh et al. 2003, Ramos et al. 2010). Polychaetes of the family Serpulidae are obligate sedentary suspension-feeders that secrete calcareous tubes and use the anterior crown of branchial radioles for both feeding and respiration. Serpulids are most abundant at low latitudes and less common in Arctic and Antarctic waters (ten Hove \& Kupriyanova 2009).

The family was traditionally subdivided into the subfamilies Serpulinae Rafinesque, 1815, Filograninae Rioja (1923) and Spirorbinae Chamberlin, 1919, until Pillai (1970) erected the Spirorbidae. The new family was widely accepted for over 20 years, until new phylogenetic data (e.g., Fitzhugh 1989, Smith 1991, Kupriyanova 2003, Kupriyanova et al. 2006, Lehrke et al. 2007) indicated that spirorbins are nested inside Serpulidae, and thus, the family status of Spirorbinae is not justified. Currently the Spirorbinae is the only monophyletic clade within the Serpulidae, whereas the traditionally defined 
Serpulinae and Filograninae are paraphyletic (Kupriyanova et al. 2006). Because spirorbins are treated here as subfamily Spirorbinae, their six traditionally recognized subfamilies are thus lowered to the tribes Paralaeospirini, Spirorbini, Circeini, Romanchellini, Pileolariini and Januini, although, clearly, a revision and re-classification of the entire family Serpulidae and of the subfamily Spirorbinae are needed.

The first comprehensive account of Arctic Serpulidae was given by Wollebæk (1912), who provided descriptions and illustrations of 12 serpulid species, including two spirorbins. Wesenberg-Lund (1950a-b, 1951, 1953a-b) in a series of papers describing Arctic polychaete fauna off Iceland, Greenland, and Norway nominally mentioned 23 serpulids, including 11 spirorbins. Bergan (1953) published data on the Norwegian spirorbins, recording seven species. A new spirorbin Bushiella (Jugaria) kofiadii (Rzhavsky, 1988) widely distributed in the Arctic was previously misidentified by different authors (see Rzhavsky 1988, 2001), usually as Spirorbis granulatus (Linnaeus, 1767). Holthe (1992) compiled references for identification of polychaetes from northern European and adjacent Arctic waters, vaguely referring to "about a dozen" species of serpulids. Also Holthe (1992), who treated spirorbins as a separate family Spirorbidae, referred to "about 10 species" of spirorbids, stating that "many difficult species occur in the area". A new species, Metavermilia arctica Kupriyanova, 1993, was found off South-East coast of Greenland, in Norwegian Sea near Faroes, and off Norwegian coast of the Barents Sea (Kupriyanova, 1993a). Kupriyanova \& Jirkov (1997) conducted a detailed regional revision of Arctic serpulids that resulted in re-description of 12 species, but no spirorbins were included in that study. Kupriyanova \& Badyaev (1998) studied ecological correlates of distribution in the species of Kupriyanova \& Jirkov (1997). Rzhavsky (2001) revised the spirorbin fauna (as family Spirorbidae) of the Arctic Ocean numbering at the time 20 species with detailed descriptions. The most recent addition to the list of Arctic serpulids was Bathyvermilia islandica Sanfilippo (2001) described from deep locations off Iceland.

Despite a relatively low number of species of Arctic serpulids, their identification still presents some challenges, mainly because of the generally confused state of the family's taxonomy. Here we report two news species from Barents Sea off Norwegian coasts.

\section{MATERIAL AND METHODS}

The serpulids were collected mainly during various monitoring cruises organized by Akvaplan-Niva, Norway and cruises within the MAREANO mapping programme of the Institute of Marine Research, Norway (see www.mareano.no). Specimens were fixed in $4 \%$ formalin and then preserved and stored in $70 \%$ ethanol. The type material is deposited in the collection of University Museum of Bergen, University of Bergen, Norway (ZMBN), Australian Museum, Sydney, Australia (AM), Zoological Institute of the Russian Academy of Science,
St. Petersburg, Russia (ZISP), and the private collection of the first author stored in A. N. Severtsov Institute of Ecology and Evolution, Russian Academy of Sciences, Moscow (IEE).

Before examination, intact specimens of Protis sp. $\mathrm{n}$ were removed from their tubes and stained with methylene blue to reveal specific glandular fields. Specimens were viewed under a dissecting microscope and photographed with a digital camera, and line drawings were made with help of a camera lucida. Chaetal structure and distribution of Bushiella sp. n. were examined on temporal glycerin slides. One specimen of Protis and two specimens of Bushiella were examined under scanning electron microscopes Leo 435VP and Vega Tescan at the Australian Museum and A.N. Severtsov Institute of Ecology and Evolution of the Russian Academy of Sciences respectively.

\section{RESULTS}

Subfamily Filograninae Rioja, 1923

Diagnosis. Tube not spirally coiled, body symmetrical, collar chaetae simple or with special fin-and blade chaetae; thoracic sickle (Apomatus) chaetae present; abdominal chaetae flat geniculate.

Remarks. Subfamily Filograninae was proposed by Rioja (1923) who stated that "presence of pinnules on the opercular peduncle ... indicates that the species included in this subfamily are very primitive, ..., corroborated by a hardly developed operculum" (Rioja 1923: 107). Because Rioja (1923) mentioned Protis as a possible member of the group, we attributed the new species to Filograninae. However, recent phylogenetic studies (e.g., Kupriyanova et al. 2006, Lehrke et al. 2007) found that both traditional subfamilies Serpulinae and Filograninae were not monophyletic, so re-classification and re-formulation of the sub-family diagnoses are needed.

\section{Protis Ehlers, 1887 emended}

Type species: Protis simplex Ehlers, 1887

Diagnosis (modified from ten Hove and Kupriyanova 2009). Tube white, opaque, with or without keels, flaring peristomes absent. Granular overlay absent. Operculum absent or one or more membranous globular opercula on normal pinnulate radiole(s). Arrangement of radioles pectinate, up to 20 per lobe. Inter-radiolar membrane absent. Branchial eyes not observed. Stylodes absent. Mouth palps absent. Seven (six in Protis akvaplani sp. n) thoracic chaetigers. Collar trilobed with entire edge, tonguelets absent. Thoracic membranes typically to the end of thorax (mid-thorax in Protis akvaplani) and may form ventral apron. Collar chaetae fin-and-blade and limbate. Apomatus chaetae present. Thoracic uncini saw-shaped with about six teeth, anterior fang simple pointed. Triangular depression absent. Abdominal chaetae flat narrow geniculate 
with rounded teeth, slightly more triangular blade in Protis hydrothermica ten Hove \& Zibrowius, 1986. Abdominal uncini rasp-shaped in all segments, with up to six teeth in profile, approximately 5-7 teeth in a row above fang. Achaetous anterior abdominal zone absent. Long posterior capillary chaetae present. Posterior glandular pad may be present.

Remarks. According to the original diagnosis, the lack of an operculum was considered a characteristic feature of Protis Ehlers, 1887. Ten Hove \& Zibrowius (1986) reformulated the diagnosis. Following the description of the abyssal Protis polyoperculata Kupriyanova, 1993 the diagnosis was extended to include individuals with one or more opercula (Kupriyanova 1993; Kupriyanova \& Jirkov 1997). Here we further emend the diagnosis to include the new species from the Barents Sea.

\section{Protis akvaplani sp. $\mathrm{n}$.}

(Figures 1-2)

\section{Material examined.}

Holotype. Body $5 \mathrm{~mm}$ long, without tube (ZMBN 87995),

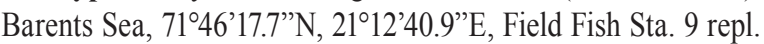
4 and 5, 23 May 2010, $317 \mathrm{~m}$, coll. Akvaplan-Niva team.

Paratypes. One specimen in tube (AM W.39543), 7 mm long, same location as holotype; two specimens, one with operculum, other without operculum, both in tubes (AM W.39541), Barents

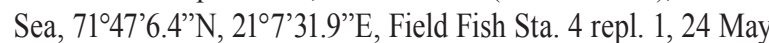
2010, 317 m, coll. Akvaplan-Niva team; one specimen without operculum, prepared for SEM (AM W.39542), Barents Sea,

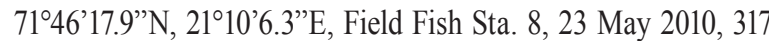
$\mathrm{m}$, coll. Akvaplan-Niva team; one specimen body $3.5 \mathrm{~mm}$ long with operculum (ZMBN 87996), Barents Sea, 71046'18.0"N, 21 7’31.6”E, Field Fish Sta. 7, 24 May 2010, 71, 316 m, coll. Akvaplan-Niva team; one specimen with operculum, body $5 \mathrm{~mm}$ long (ZMBN 87997), Barents Sea, 71³7’34.8”N, 16¹8'10.2”E, MAREANO Sta. 578, 9 August 2010, 586 m, collected by team of Norwegian Institute of Marine Research, Bergen.

\section{Description.}

Tube: White, entirely opaque, circular in cross section, mostly attached to substratum (although only tube fragments were present in the material), with very distinct high sharp longitudinal keel (Figures 1C, 2A).

Size: Total length up to $7 \mathrm{~mm}$; branchiae account for approximately one third of entire length. Width of thorax 0.4 $\mathrm{mm}$, operculum diameter $0.4 \mathrm{~mm}$ (Figure $1 \mathrm{~A}-\mathrm{B}$ ).

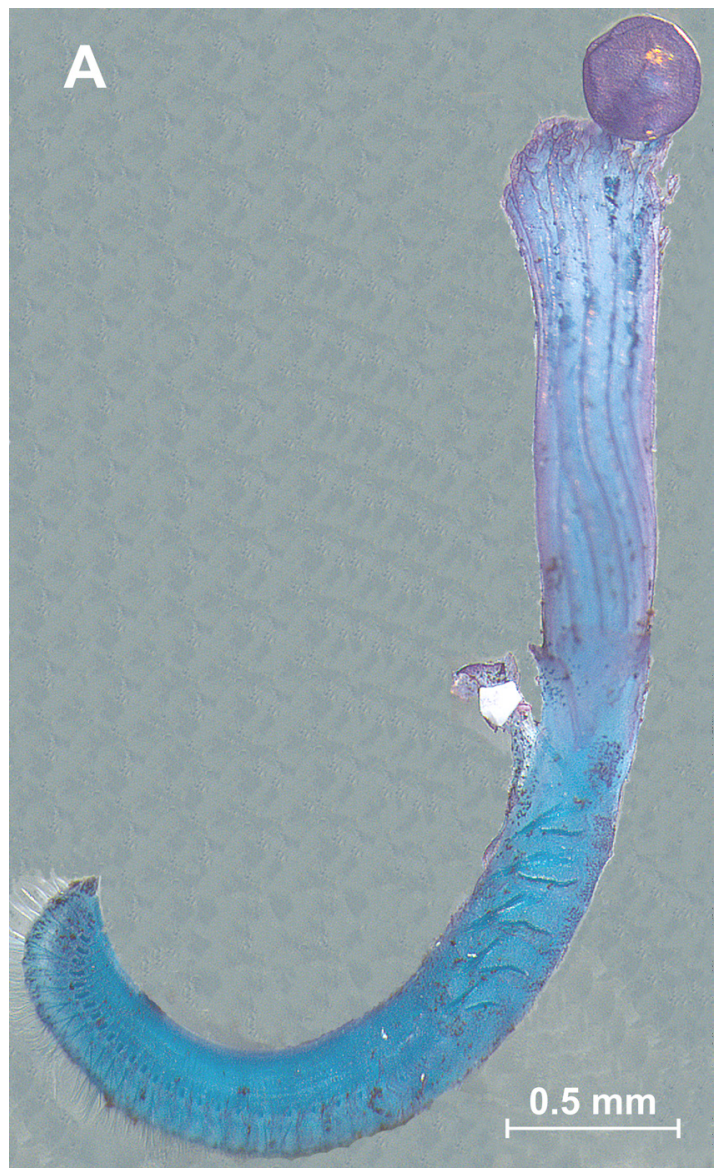

\section{B}

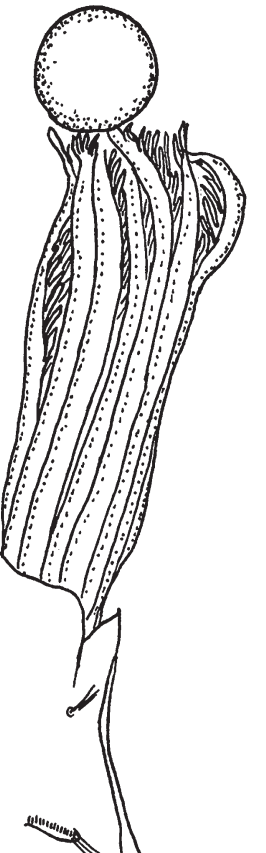

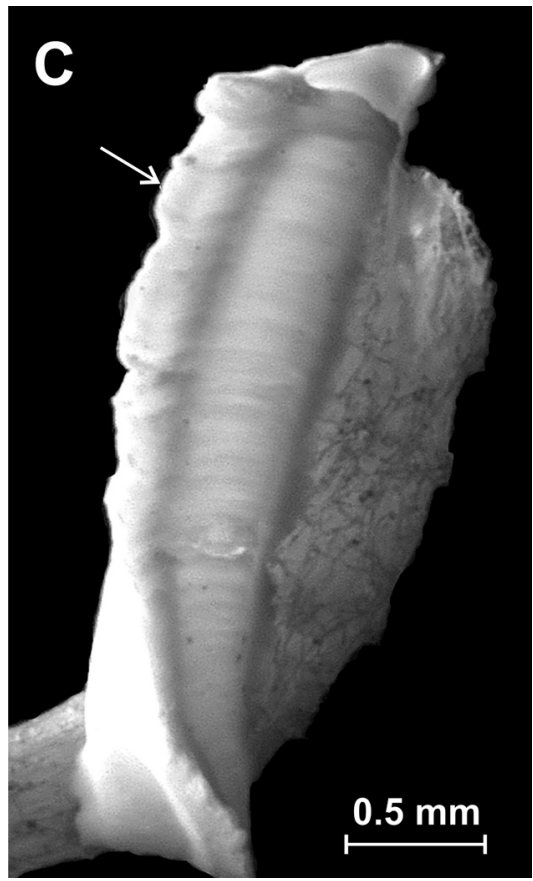

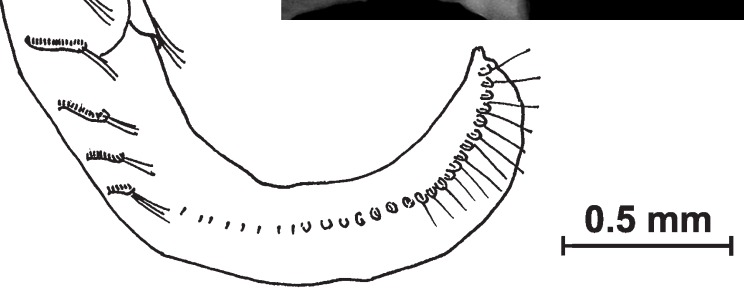

Figure I. Photos and line drawings of Protis akvaplani n. sp. A: entire body photo; B: entire body line drawing; C: photo of tube fragment, arrow indicates longitudinal keel. A,-B: holotype ZMBN 87995; C: paratype AM W.39543. Photo A and C: Elena Kupriyanova. 



Figure 2. Scanning electron microscopy (SEM) micrographs of Protis akvaplani sp.n. AM W.39542. A: tube, arrow points to high longitudinal keel; B: lateral view of thorax with five uncinigerous segments; C: dorsal view of thorax showing the length of thoracic membranes; D: bundle of collar chaetae; E: details of special collar chaetae structure; F: thoracic chaetal bundle with Apomatus chaetae; G: abdominal chaeta; H: thoracic uncini; I: abdominal uncini. Photo: Sue Lindsay. 
Branchiae: Each lobe bearing five branchial radioles with long thin pinnules, arranged pectinately, not connected by a branchial membrane. Branchial eyes and distinct long terminal pinnules absent.

Operculum: Absent or present, if present, a membranous transparent globular vesicle (Figure 1 A, B) on normal pinnulated second branchial radiole. Pseudoperculum absent.

Collar and thoracic membranes: Collar with entire edge, large, covering branchial lobes. Trilobed, medio-ventral lobe distinctly higher and wider than lateral lobes; collar continuous with wide thoracic membranes ending as rounded flaps after $3^{\text {th }}$ thoracic segment, no apron (Figures 1 A-B, 2 B-C). Pairs of small, wart-like protuberances of collar chaetiger absent; tonguelets between ventral and lateral collar parts absent.

Thorax: With collar chaetiger and five uncinigerous chaetigers (Figures 1 A-B, 2 B). Collar chaetae bundle (Figure 2 D) including simple limbate and special fin-and-blade chaetae, with distally blade separated from proximal dentate zone by wide gap (Figure 2 E). Subsequent chaetae simple limbate, of two sizes, Apomatus chaetae present in posterior thoracic segments (Figure $2 \mathrm{~F}$ ). Uncini along entire thorax saw-shaped, with 5-6 slightly curved teeth and simple pointed fang (Figure $2 \mathrm{H})$. Prostomial eyes not observed.

Abdomen: Up to 40 abdominal chaetigers. Achaetous anterior abdominal zone absent. Uncini rasp-shaped, with simple pointed fang and 7-8 teeth in profile (Figure 2 I). Abdominal chaetae flat narrow geniculate with rounded teeth and tapered tip (Figure $2 \mathrm{G}$ ). Distinct long capillary chaetae present in posterior chaetigers. Posterior glandular pad present.

Colour: Colour of live specimens unknown. Preserved material white.

\section{Differential diagnosis and remarks.}

According to ten Hove and Kupriyanova (2009), the genus Protis contains six (or seven if nominal taxon Salmacina chilensis Gallardo, 1969 belongs to this genus) poorly known species mainly from bathyal and abyssal locations. The taxonomy of the genus is problematic because the chaetae, uncini, and tubes are very similar and opercula, if present, are undifferentiated membranous vesicles.

Both operculate and non-operculate species are described; moreover, Protis arctica (Hansen, 1878) and P. polyoperculata Kupriyanova, 1993 have been reported to contain both operculate and non-operculate specimens (Kupriyanova 1993, Ben-Eliahu \& Fiege 1996, Kupriyanova \& Jirkov 1997). Protis hydrothermica shows two characters not mentioned for the other species: warts between ventral and lateral collar lobes and a pair of pockets in the medio-ventral collar.
The new species appears to be similar to $P$. arctica that was originally described based on two specimens collected between Iceland and Norway from $2127 \mathrm{~m}$; the same specimens were later redescribed by Wollebæk (1912). Kirkegaard (1982) reported two specimens of $P$. arctica collected from the abyssal depths of the Central Arctic, but gave neither diagnosis nor details of chaetae and uncini. Kupriyanova \& Jirkov (1997) reported several specimens from the depths of 795-1820 m mostly from north of Iceland. Those specimens are relatively larger, measuring $5-25 \mathrm{~mm}$ less branchia, that is, over $30 \mathrm{~mm}$ in total length.

Although species within the genus Protis are difficult to distinguish, $P$. akvaplani sp. nov. shows very distinct characters, clearly setting it apart from other species of the genus: it has only six thoracic chaetigerous segments, short thoracic membranes ending after the $3^{\text {rd }}$ thoracic chaetiger, and tube with a very distinct high longitudinal keel. However, because the chaetation pattern of the new species is consistent with that of the genus Protis, we here emend the generic diagnosis instead of erecting a new monotypic genus.

\section{Etymology.}

The species is named after Akvaplan-niva, a private company providing environmental consultancy and research, in both coastal waters and offshore, within the NIVA-group (Norwegian Institute of Water Research).

Ecology.

Found at depths of 316-317 and $586 \mathrm{~m}$.

\section{Distribution.}

South-western Barents Sea, Norway.

\section{Subfamily Spirorbinae Chamberlin, 1919}

Tube spirally coiled dextrally or sinistrally; body asymmetrical, abdomen turned over thorax 90 degrees in achaetigerous zone between thorax and abdomen; thorax adjoins to substratum dorsally; 3-5(7?) thoracic chaetigers; collar chaetae simple or with special fin-and-blade chaetae; thoracic sickle (Apomatus) chaetae usually present in 3-5 thoracic chaetigers; abdominal chaetae flat geniculate; embryos incubated in tube or in opercular brood chamber; larvae lecithotrophic, pelagic stage brief or absent.

\section{Tribe Pileolariini Knight-Jones, 1978}

Embryos within chamber (or cup) formed by invagination of opercular ampulla and may be used for more than one brood. With two types of opercula: one only distal plate with talon and another brooding chamber of various structures. Larvae with single white attachment gland. Thoracic uncini narrow (saw to rasp-shaped) with 1-3 longitudinal rows of teeth throughout most length of uncinus and blunt anterior peg. Abdominal uncini distributed symmetrically. Largest abdominal tori located in 
anterior or posterior half of abdomen. Abdominal chaetae flat geniculate, pennant-shaped, usually with thick (optically dense) projecting heel; blade length usually somewhat shorter than that of largest collar chaetae, width decreases regularly toward tip.

\section{Bushiella Knight-Jones, 1973}

Type-species: Spirorbis evolutus Bush, 1905

Diagnosis. Tubes always sinistral. Talon of distal plate peripheral and flattened, generally large; distal plate retained and fused to the brood chamber completely or only by talon; brood chamber a deeply invaginated sac totally enclosing embryos except for a pore capable of opening and closing; lining of brood chamber forming a calcified dome distally, but not calcified proximally or on side bearing the pore. Collar and thoracic membrane margins not fused over thoracic groove. Collar chaetae simple or with basal fins and finely or moderately serrated blades which usually lack distinct cross-striation; sickle chaetae present in $3^{\text {rd }}$ thoracic fascicles. Three thoracic chaetigers.

Remarks. There are two subgenera $B$. (Bushiella) Knight-Jones, 1973 with simple collar chaetae and B. (Jugaria) Knight-Jones, 1978 with fin-and blade collar chaeta. Knight-Jones (1984) suggested them being valid genera based on this feature only. In our opinion (Rzhavsky 1991), it is not sufficient for the generic sub-division considering that in some species collar simple chaetae may have their base somewhat swollen and, thus, can be regarded as intermediate between simple and special finand-blade chaetae (e.g., Bushiella (Bushiella) evoluta (Bush, 1905); Knight-Jones 1984). Also, species of genus Eulaeospira have both types of collar chaetae (Knight-Jones et al. 1974, Knight-Jones \& Fordy 1979) and subgenera Paradexiospira and Spirorbides of genus Paradexiospira also differ only in collar chaetae structure (Knight-Jones et al., 1979; Knight-Jones \& Fordy 1979). Therefore, in the interests of consistency, the new species here is attributed to the subgenus Bushiella.

\section{Subgenus Bushiella Knight-Jones, 1973}

Diagnosis. Collar chaetae simple; a groove may present in basal part of their blades, sometimes very distinct and bearing teeth, but fin never forms, i.e., smooth gap between basal toothed groove and serrated blade absent. Cross-striation absent.

Type species: Spirorbis evolutus Bush, 1905

\section{Bushiella (Bushiella) barentsii sp. n.} (Figures 3-5)

\section{Material examined.}

Spitsbergen Bank, Barents Sea, 7607'N, 23051'48”E, 8 August 1992, Sta. 11-1, 11-3, 11-4, 59 m, stones, with glacial bluegray clay in deeper layers, and recent reddish deposits inbetween stones. Tubes were mostly detached from substrate, but two specimens were attached to small shell fragments.
Coll. Akvaplan-niva (wider data set analysed in Cochrane et al. 2012).

Holotype. Station 11-1. Body with tube and brood chamber (ZISP 1/50577)

Paratypes. Station 11-1. One adult specimen with brood chamber and tube fragments (ZISP 2/50578); five specimens with primary operculum (no brood chamber) and tubes (3/50579); two specimens without operculum, prepared for SEM (IEE 1/2859); two adults with brood chamber without tubes (IEE $2 \mathrm{a} / 2860,2 \mathrm{~b} / 2860$ ), three specimens with primary operculum (no brood chamber) without tubes (IEE 2c/2860, $2 \mathrm{~d} / 2860,2 \mathrm{e} / 2860)$; seven partially destructed empty tubes and their fragments (IEE 2f/2860); one adult specimen with brood chamber associated with tube (ZMBN 87991).

Station 11-3. One adult specimen with brood chamber without tube (IEE 3a/2861), one specimen with primary operculum (no brood chamber) without tube (IEE 3b/2861); four specimens with primary operculum (no brood chamber) without tubes (IEE 3c/2861); four partially destructed empty tubes and their fragments (IEE 3d/2861); one adult with brood chamber without tube (ZMBN 87992); five specimens with primary operculum (no brood chamber) without tubes (ZMBN 87993); five partially destructed empty tubes and their fragments (ZMBN 87994).

Station 11-4. Two specimens with primary operculum (no brood chamber) associated with tubes (IEE 4a/2862); one empty tube (IEE 4b/2862); two adults with brood chamber without tubes (AM W.41417); four specimens with primary operculum (no brood chamber) without tubes (AM W.41418); seven partially broken empty tubes and their fragments (AM W. 41419).

\section{Description.}

Tube: Sinistral, planospiral with 2-3 (one in juveniles) distinct longitudinal ridges, up to $4-5 \mathrm{~mm}$ in coil diameter, white opaque (non porcellanous) (Figure $3 \mathrm{~A}-\mathrm{C}$ ).

Branchiae: Number not counted due to adhesion caused by partial drying and breaking off during examination.

Operculum: Primary operculum of juveniles with concave distal plate which deeper in immature specimens of adult size (Figure 4 G-J). Talon almost lateral, large and winged laterally (Figure $4 \mathrm{G}-\mathrm{H}$ ), sometimes of irregular rhomboid shape (Figure 4 I). Distal part of talon pointed or sometimes slightly bifurcated (Figure 4 H-I). Primary operculum almost completely fused with brood chamber after it its complete development: distal plate of primary operculum fused with distal part of brood chamber only in the central part and side close to talon, leaving space between distal plate and brood chamber on the opposite side and laterally (Figure 4 A-D). This free edge may be broken giving an illusion that primary operculum completely fused 
with brood chamber, but in this case central fused part of distal plate visible as a spot on distal part of brood chamber (Figure 4 E). Talon completely fused with lateral wall of brood chamber (Figure $4 \mathrm{~A}, \mathrm{D}-\mathrm{F}$ ). Calcified zone of lateral wall very distinct and long on side of talon (Figure 4 A-B, D-F); distal edge of calcified zone irregular and rounded (Figure 4 A, D), sometimes denticulate with its surface looking somewhat fluted (Figure 4 F). On side opposite from talon calcified zone resembling a narrow belt adjacent to distal part of brood chamber. (Figure 4 B). Brooding specimens absent in studied material.

Collar and thoracic membranes: With free dorsal margins, posterior edges of thoracic membranes reach the end of the third chaetiger, apron present.

Thorax: Three pairs of the notochaetae visible from side facing substrate (Figure 3 D-E). Special collar chaetae bent, simple, with finely serrated blade without cross-striation (Figure $5 \mathrm{Aa}$, $\mathrm{Bco}$ ), capillary chaetae also present in first fascicle (Figure
$5 \mathrm{Ab}, \mathrm{Bca})$. Chaetae of $2^{\text {nd }}$ and $3^{\text {rd }}$ thoracic chaetigers simple (Figure 5 Ac, C, Dsi). Sickle (Apomatus) chaetae (Figure 5 Ad, Dap) with coarsely serrated blades and smooth basal parts also present in the $3^{\text {rd }}$ fascicle. Two thoracic tori on each side of body on $2^{\text {nd }}$ and $3^{\text {rd }}$ chaetigers. Thoracic uncini saw to rasp-shaped (Figure $5 \mathrm{Ag}, \mathrm{E}$ ) with blunt anterior pegs and 1-3 longitudinal rows of teeth throughout most length of uncinus. Size of individual uncini in each torus significantly decreasing away from notochaetae. Smallest thoracic uncini only somewhat longer than abdominal uncini, largest about three times longer.

Abdomen: About 20-25 abdominal chaetigers in juveniles and over 35 in adults. Achaetous anterior abdominal zone present. Two abdominal chaetae per fascicle throughout length of abdomen, but some anterior abdominal chaetigers bearing three chaetae and posterior only one. Chaetae flat geniculate, with "knee" projecting beyond shaft and distinctly serrated tapering blade (Figure 5 Ae, Fag). One companion hooked capillary chaetae (Figure $5 \mathrm{Af}$, Fah) per fascicle present in the most
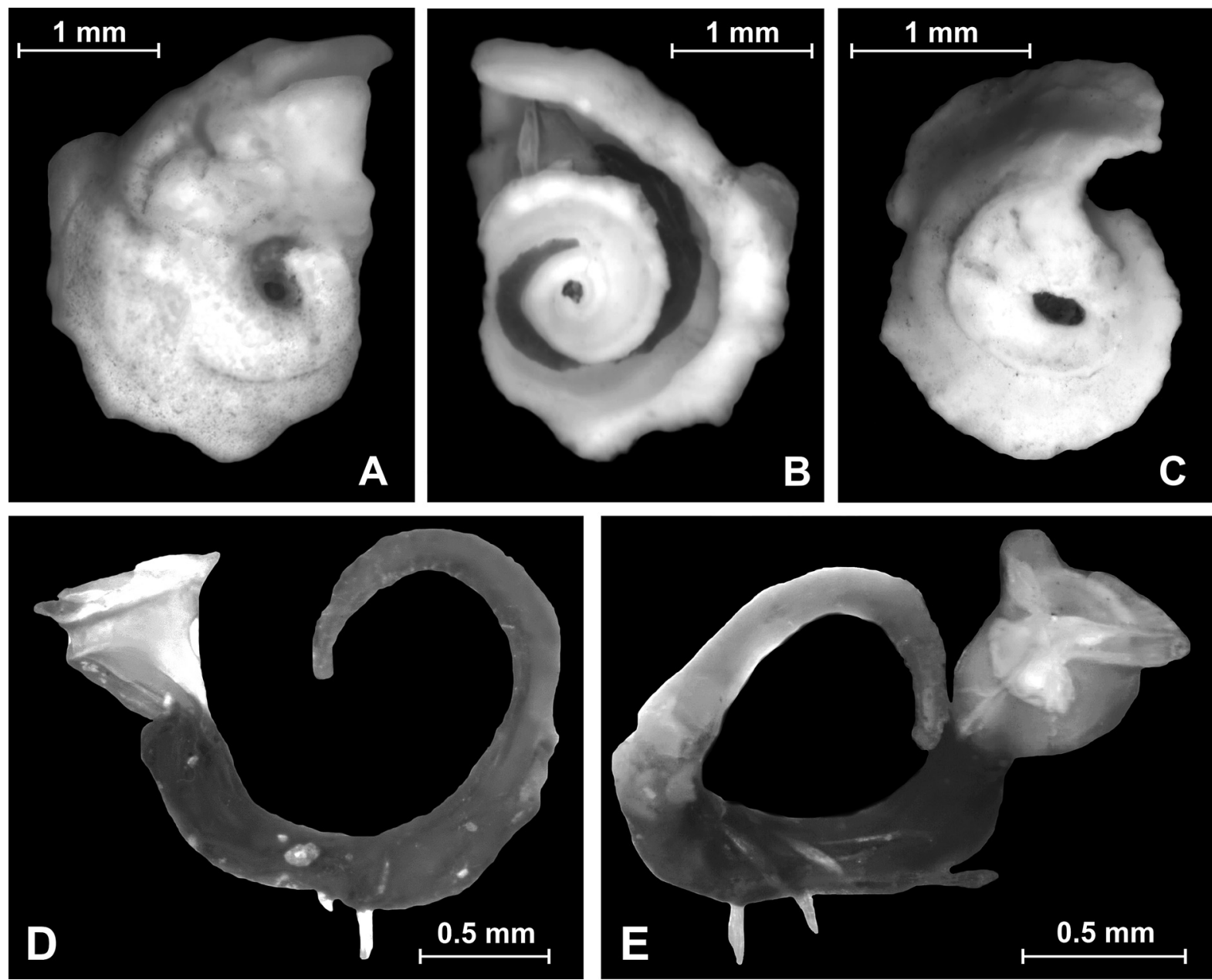

Figure 3. Photos of Bushiella (B.) barentsii sp. n., tube and body. A: tube with two longitudinal ridges, top view; B: body inside the tube detached from substratum, view from the side of substratum; $\mathrm{C}$ : tube with one longitudinal ridge, top view; D: entire body in the natural position; E: entire body, view from the substrate side, three thoracic fascicles are visible. A-B, D-E: holotype ZISP 1/50577; C: paratypes IEE 4b/2862. Photo: Alexander V. Rzhavsky. 

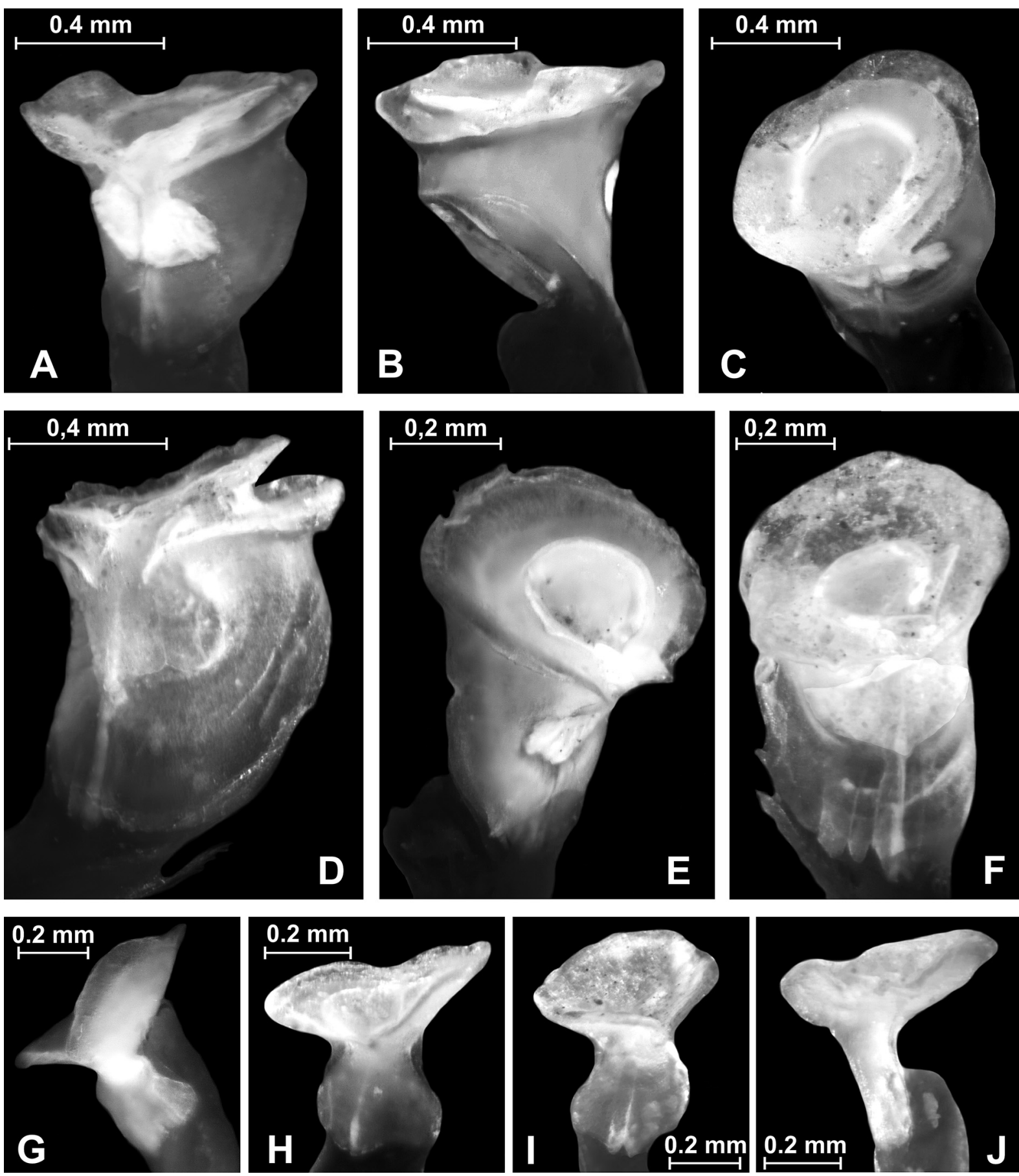

Figure 4. Photos of Bushiella (B.) barentsii sp. n., operculum. A-C: empty brood chamber with completely fused primary operculum, front, lateral and top views respectively; D: brood chamber with complete fused primary operculum, distance between distal part of brood chamber and free edge of primary operculum plate is well visible, front-lateral view; E: brood chamber with bracken free edge of primary operculum plate, top-lateral view; F: brood chamber with serrated fluted edge of calcareous zone on the lateral wall, top-frontal view; G: primary operculum of the specimen of adult size, front-lateral view; H: primary operculum of juvenile (small size) specimen with typical talon, front view; I: primary operculum of juvenile (small size) specimen with rhomboid talon and bifurcated distal end, front view; J: primary operculum of juvenile (small size) specimen, lateral view. A-C: holotype; D: paratype 2a/2860; E: paratype 3a/2861; F: paratype 2b/2860; G: paratype 3b/2861; H: paratype 2d/2860; I-J: paratype 2c/2860. Photo: Alexander V. Rzhavsky. 

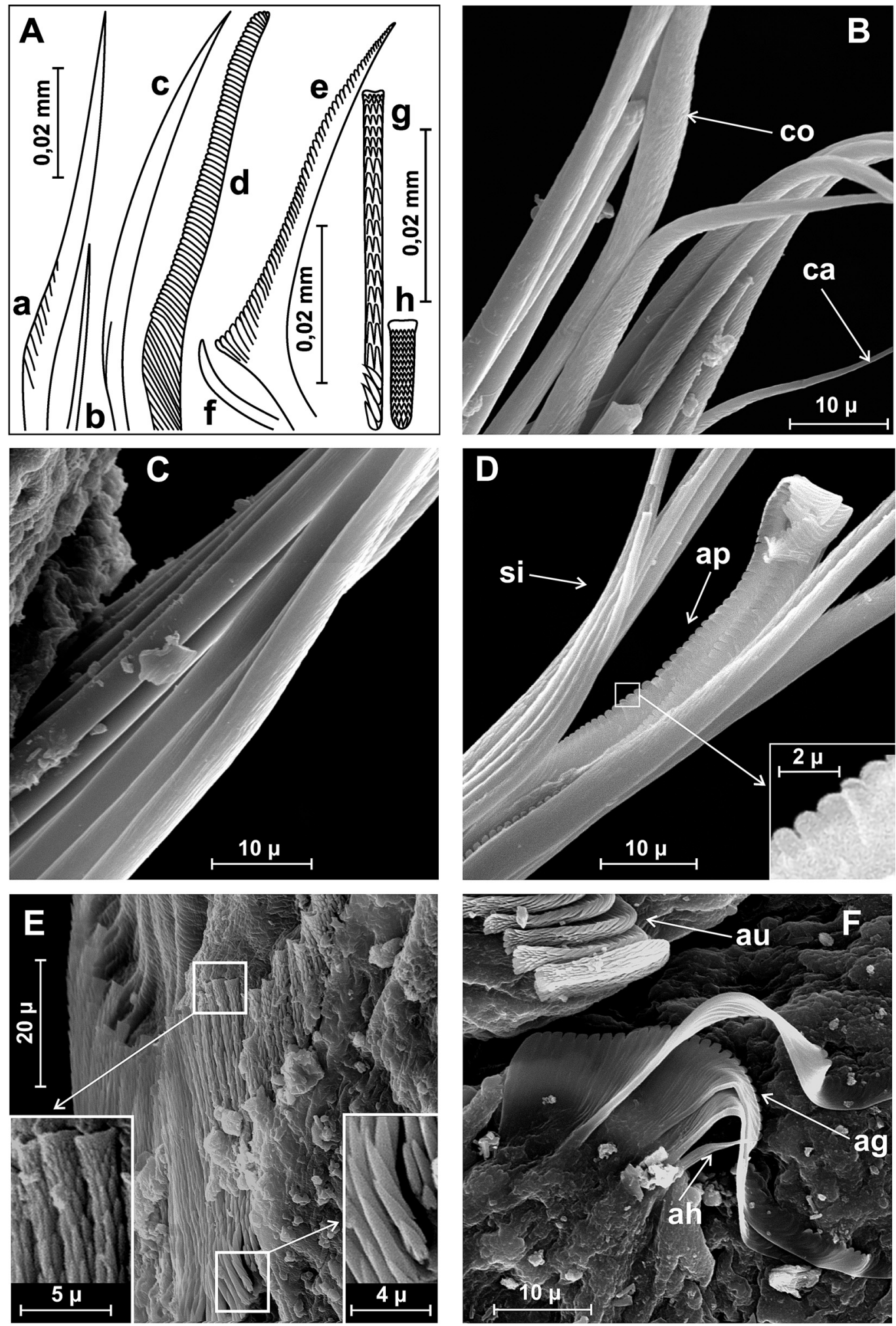

Figure 5. Line drawings (A) and scanning electron microscopy (SEM) micrographs (B-F) of Bushiella (B.) barentsii sp. n., chaetae. Aa: collar chaeta; Ab: companion capillary chaeta of the $1^{\text {st }}$ chaetiger; Ac: simple chaeta off the $2^{\text {nd }}$ chaetiger; Ad: sickle chaeta off the $3^{\text {rd }}$ chaetiger; Ae: abdominal flat geniculate chaeta; Af: abdominal companion capillary hooked chaeta; Ag: large thoracic uncinus; Ah: abdominal uncinus; B: collar chaetae (co) and companion capillary chaeta (ca) off the $1^{\text {st }}$ chaetiger; C: simple chaetae off the $2^{\text {nd }}$ chaetiger; D: simple (si) and sickle (Apomatus) (ap) chaetae off the $3^{\text {rd }}$ chaetiger; E: thoracic uncini; F: abdominal chaetae: flat geniculate (af), capillary hooked (ah) and uncini (au). A: holotype; B-F: paratypes IEE 1/2859. Photo B - F: Nadezhda Surovenkova. 
fascicles. Abdominal uncini (Figure 5 Ah, Fau) rasp-shaped with blunt anterior pegs and numerous longitudinal rows of teeth, distribution fairly symmetrical on both sides of body. Largest tori in middle-posterior part of abdomen.

Colour: Colour of live specimens unknown. Preserved specimens are dark brown probably as a result of temporary period of desiccation.

\section{Differential diagnosis and remarks.}

The new species differs from all other thirteen species of Bushiella in having an unusual structure of its mature brood chamber. Except for Bushiella (Bushiella) abnormis (Bush, 1905) having multiple primary opercula (several primary opercula forming one above the other, with their talons interconnected by a sclerotinized strand, see Figure 6 D $(a, b)$ in Knight-Jones et al. 1979), all other species form only a single opercular plate that is completely fused with the distal part of brood chamber after its development (e.g., Bushiella (Jugaria) similis (Bush, 1905), B. (Jugaria) quadrangularis (Stimpson, 1854), B. (B.) evoluta, see Knight-Jones et al. 1979; KnightJones 1984) or firmly attached to the lateral wall of mature brood chamber by talon only, leaving some space between the plate of primary operculum and the distal part of the brood chamber (e.g. Bushiella (Jugaria) granulata (Linnaeus, 1767), Bushiella (Bushiella) valida (Verrill in Smith and Harger, 1874), see Knight-Jones et al. 1979; Knight-Jones 1984). Based on this feature, $B$. (B.) barentsii sp. n. occupies an intermediate position: the distal plate of primary operculum is fused with the distal part of the brood chamber only in the central part and with the side adjacent to the talon, leaving space between the distal plate and brood chamber on the opposite side and laterally. However, very careful observations are needed because the free edge of the primary operculum may be broken, giving an illusion that the primary operculum is completely fused with brood chamber; when this is the case, the central fused part of distal plate visible as a spot on the distal part of the brood chamber.

Another characteristic feature that distinguishes the new species from other species of Bushiella is the calcified zone of the lateral wall of brood chamber. This zone is very extensive, distinct and of irregular, approximately rounded shape; its distal edge sometimes may be denticulate and the surface looks somewhat fluted. Other species lack the lateral calcified zone like B. (B.) evoluta (see Knight-Jones 1984), but if the zone is present, it is either indistinct as in Bushiella (Jugaria) acuticostalis (Rzhavsky, 1991) (see Rzhavsky 1991) or distinct, but with smooth, even distal edge as in $B$. $(J$.$) similis, B .(J$. quadrangularis, B. (B.) valida (see Knight Jones et al. 1979, Knight-Jones 1984).

Immature specimens of $B(B$.) barentsii lack brood chambers and may be distinguished by the talon morphology. The talons are large and winged laterally, of irregular form. Sometimes they may resemble heart-shaped talons of $B$. (B.) valida (see
Figure 2A in Knight-Jones 1984). Finally, B. (B.) barentsii and $B$. (B.) valida are the only two Bushiella species reaching 4-5 $\mathrm{mm}$ or larger in coil diameter, whereas members of all the other species do not exceed $3 \mathrm{~mm}$. However, $B$. (B.) valida has tubes lacking any longitudinal ridges, whereas tubes of $B$. (B.) barentsii bear 1-2 distinct longitudinal ridges. Moreover, some juvenile specimens have rhomboid (diamond-shaped) talons similar to that of $B$. (J.) quadrangularis, but the latter species has a domed distal opercular plate (see Knight-Jones et al. 1991, Figure $4 \mathrm{a}-\mathrm{c}$ ) and belongs to subgenus with distinct fin-andblade collar chaeta.

\section{Etymology.}

The species is named after the Barents Sea where it was found.

\section{Ecology.}

Found at $56 \mathrm{~m}$ deep. Substrate is unknown, small shell fragments were attached to the bottom of two specimens. Based on the tube morphology (Rzhavsky 1994), the new species most likely occupies hard substrata, such as shells and stones and, probably, carapaces of large decapods.

Distribution.

Spitsbergen Bank, Barents Sea.

\section{ACKNOWLEDGMENTS}

This study received supplementary funding from Akvaplanniva. We thank Sue Lindsay from the Australian Museum, Sydney and Nadezhda N. Surovenkova from Institute of Ecology and Evolution, Moscow for their help with scanning electron microscopy, and Sabine Cochrane from Akvaplan-niva for her linguistic corrections and valuable editorial comments.

\section{REFERENCES}

Ben-Eliahu MN, Fiege D. 1996. Serpulid tube-worms (Annelida: Polychaeta) of the central and eastern Mediterranean with particular attention to the Levant Basin. Senckenbergiana Maritima 28: 1-51.

Bergan P. 1953. The Norwegian species of Spirorbis (Daudin). Nytt Magasin for Zoologi 1: 27-48.

Bush KJ. 1905. Tubicolous annelids of the tribes Sabellides and Serpulides from the Pacific Ocean. Harriman Alaska Expeditions 12: 169-355.

Chamberlin RV. 1919. The Annelida Polychaeta. Memoirs of the Museum of Comparative Zoology at Harvard College 48: 1-514.

Chambers SJ, Woodham A. 2003. A new species of Chaetozone (Polychaeta: Cirratulidae) from deep water in the northeast Atlantic, with comments on the diversity of the genus in cold northern waters. Hydrobiologia 496: 41-48.

Cochrane SKJ, Pearson TH, Greenacre M, Costelloe J, Ellingsen 
IH, Dahle S, Gulliksen B. 2012. Benthic fauna and functional traits along a Polar Front transect in the Barents Sea Advancing tools for ecosystem-scale assessments. Journal of Marine Systems 94: 204-217.

Ehlers E. 1887. Report on the Annelids. Reports on the results of dredging, under the direction of L.F. Pourtalès, during the years 1868-1870, and of Alexander Agassiz, in the Gulf of Mexico, and in the Caribbean Sea, in the U.S. Coast Survey Steamer "Blake". Memoirs of the Museum of Comparative Zoology, Harvard 15: 1-335.

Fitzhugh K. 1989. A systematic revision of the SabellidaeCaobangiidae-Sabellongidae complex (Annelida: Polychaeta). Bulletin of the American Museum of Natural History 192: $1-104$.

Gallardo VA. 1969. Description of Salmacina chilensis n. sp. (Polychaeta, Serpulidae) from northern Chile. Boletín de la Sociedad de Biologia de Concepción 41: 9-12

Hansen GA. 1878. Annelider fra den norske Nordhavsexpedition 1876. Nyt Magazin for Naturvidenskaberne 24: 1-17.

Holthe T. 1992. Identification of Annelida Polychaeta from Northern European and adjacent Arctic waters. Gunneria 65: $1-30$.

Hove HA ten, Kupriyanova, EK. 2009. Taxonomy of Serpulidae (Annelida, Polychaeta): the state of affairs. Zootaxa 2036: 1126.

Hove HA ten, Zibrowius H. 1986. Laminatubus alvini gen. et sp. n. and Protis hydrothermica sp. n. (Polychaeta, Serpulidae) from the bathyal hydrothermal vent communities in the eastern Pacific. Zoologica Scripta 15: 21-31.

Kirkegaard JB. 1982. New records of abyssal benthic polychaetes from the Polar Sea. Steenstrupia 8: 253-260.

Knight-Jones EW, Knight-Jones P, Llewellyn LC. 1974. Spirorbinae (Polychaeta, Serpulidae) from southeastern Australia. Notes on their taxonomy, ecology, and distribution. Records of the Australian Museum 29(3): 107-151.

Knight-Jones P. 1973. Spirorbinae (Serpulidae: Polychaeta) from south-eastern Australia. A new genus, four new subgenera and seven new species. Bulletin of the British Museum Natural History (Zoology) 24(4): 231-259.

Knight-Jones P. 1978. New Spirorbidae (Polychaeta: Sedentaria) from the East Pacific, Atlantic, Indian and Southern Oceans. Zoological Journal of the Linnean Society 64(3): 201-240.

Knight-Jones P. 1984. A new species of Protoleodora (Spirorbidae: Polychaeta) from eastern U.S.S.R., with a brief revision of related genera. Zoological Journal of the Linnean Society 80(23): 109-120.

Knight-Jones P, Fordy MR. 1979. Setal structure, functions and interrelationships in Spirorbidae (Polychaeta: Sedentaria). Zoologica Scripta 8(2): 119-138.

Knight-Jones P, Knight-Jones EW, Buzhinskaja GN. 1991. Distribution and interrelationships of northern spirorbid genera. Bulletin of Marine Science 48(2): 189-197.

Knight-Jones P, Knight-Jones EW, Dales RP. 1979. Spirorbidae (Polychaeta: Sedentaria) from Alaska to Panama. Journal of Zoology 189(4): 419-458.

Koh B-S, Bhaud MR, Jirkov IA. 2003. Two new species of Owenia (Annelida: Polychaeta) in the northern part of the North Atlantic Ocean and remarks on previously erected species from the same area. Sarsia 88: 175-188.
Kupriyanova EK. 1993a. Metavermilia arctica sp. n. (Serpulidae, Polychaeta) from the Arctic Ocean. Sarsia 78: 155-157.

Kupriyanova EK 1993b. Deep-water Serpulidae (Annelida, Polychaeta) from the Kurile-Kamchatka trench: 2. Genera Bathyditrupa, Bathyvermilia and Protis. Zoologicheskii Zhurnal, 72: 21-28 (In Russian).

Kupriyanova EK. 2003. Life history evolution in Serpulimorph polychaetes: a phylogenetic analysis. Hydrobiologia 496: 105114.

Kupriyanova EK, Badyaev AV. 1998. Ecological correlates of Arctic Serpulidae (Annelida, Polychaeta) distributions. Ophelia 49(3): 181-193.

Kupriyanova EK, Jirkov IA. 1997. Serpulidae (Annelida, Polychaeta) of the Arctic Ocean. Sarsia 82: 203-236.

Kupriyanova EK, Macdonald TA, Rouse GW. 2006. Phylogenetic relationships within Serpulidae (Annelida: Polychaeta) inferred from molecular and morphological data. Zoologica Scripta 35: 421-439.

Lehrke J, Hove, HA ten, Macdonald TA, Bartolomaeus T, Bleidorn C. 2007. Phylogenetic relationships of Serpulidae (Annelida, Polychaeta) based on $18 \mathrm{~S}$ rDNA sequence data and implications for opercular evolution. Organisms, Diversity and Evolution 7: 195-206.

Linnaeus C. [as Linné C.] 1767. Systema naturae sive regna tria naturae, secundum classes, ordines, genera, species, cum characteribus, differentiis, synonymis, locis. Laurentii Salvii, Holmiae. 12th ed. 1(2): 533-1327.

Pillai TG. 1970. Studies on a collection of spirorbids from Ceylon, together with a critical review and revision of spirorbid systematics and an account of their phylogeny and zoogeography. Ceylon Journal of Science (Biological Sciences) 8: 100-172.

Rafinesque SC. 1815. L'analyse de la nature. Palermo, 224 pp.

Ramos J, San Martín G, Sikorski A. 2010. Syllidae (Polychaeta) from the Arctic and sub-Arctic regions. Journal of the Marine Biological Association of the United Kingdom 90: 1041-1050.

Rioja E. 1923. Estudio sistematico de las especies Ibericas del suborden Sabelliformia. Trabajos del Museo Nacional de Ciencias Naturales Serie Zoologica 48: 1-144.

Rzhavsky AV. 1988. Jugaria kofiadii sp.n.(Polychaeta, Spirorbidae) from the Arctic Basin. Zoologicheskii Zhurnal 67(6): 50-58 (in Russian).

Rzhavsky AV. 1991. Composition of the genus Bushiella (Polychaeta, Spirorbidae) and distribution of its representatives in the seas of the USSR; description of a new species. Zoologicheskii Zhurnal 70(3): 5-11 (in Russian).

Rzhavsky AV. 1994. On the morphoecology of spirorbid tubes (Polychaeta: Spirorbidae). Ophelia 39(3): 177-182.

Rzhavsky AV. 2001. Spirorbidae. - In Jirkov IA (ed.). Polychaeta of the Arctic Ocean. Moscow, Yanus-K Press. pp 572-606 (in Russian).

Sanfilippo R. 2001. Bathyvermilia islandica (Polychaeta, Serpulidae): a new deep-water species from south of Iceland. Sarsia 86: 177-182.

Smith RS. 1991. Relationships within the order Sabellida (Polychaeta). Ophelia Supplement 5: 249-260.

Smith SI, Harger O. 1874. Report on the dredgings in the region of St. Georges Banks in 1872. Transactions of the Connecticut Academy of Arts and Sciences 3: 1-57.

Stimpson W. 1854. Synopsis of the marine invertebrata of Grand 
Manan: or the region about the mouth of the Bay of Fundy, New Brunswick. Smithsonian Contributions to Knowledge 6(5): 1-66.

Wesenberg-Lund E.1950a. Polychaeta. Danish Ingolf-Expedition 4(4): $1-92$.

Wesenberg-Lund E. 1950b. The Polychaeta of West Greenland with special reference to the fauna of Nordre Stroemfjord, Kvaneand Bredefjord. Meddelelser om Grønland 151(2): 1-171.

Wesenberg-Lund E.1951. Polychaeta. The Zoology of Iceland 2(19): 1-182.

Wesenberg-Lund E. 1953a. Serpulidae (Polychaeta) collected by C. Dons along the Norwegian coast. Det kongelige norske Videnskabers Selskabs, 1952 6: 1-22.

Wesenberg-Lund E. 1953b. The Zoology of West Greenland. Polychaeta. Meddelelser om Grønland 122(3): 1-169.

Wollebæk A. 1912. Nordeuropæiske Annulata Polychaeta. I. Ammochariae, Amphictenidae, Ampharetidae, Terebellidae og Serpulidae. Skrifer udgivet af Videnskabsselskabet i Christiana, Math.- Naturv. Kl., Pt.2: 144 pp.

Editorial responsibility: Torkild Bakken.

This article is open-access and distributed under the terms of the Creative Commons Attribution-Noncommercial 3.0 Unported License (http://creativecommons.org/licenses/by-nc/3.0/). This permits all non-commercial use, distribution, and reproduction in any medium, provided the original work is properly cited. 